\title{
Growth Rate of Eggplant Under Nitrogen and Phosphate Fertilization and Irrigated With Wastewater
}

\author{
Sebastião de Oliveira Maia Júnior ${ }^{1}$, Aldair de Souza Medeiros ${ }^{1}$, Thiago Cândido dos $\operatorname{Santos}^{1}$, \\ Mariana de Oliveira Pereira ${ }^{2}$, Renato Américo de Araújo Neto ${ }^{1}$, Giordano Bruno Medeiros Gonzaga ${ }^{1}$, \\ Manoel Moisés Ferreira de Queiroz ${ }^{2}$, Reginaldo Gomes Nobre ${ }^{3}$, Rener Luciano de Souza Ferraz ${ }^{4}$, \\ Ivomberg Dourado Magalhães ${ }^{1} \&$ Patrícia da Silva Costa $^{2}$ \\ ${ }^{1}$ Center for Agrarian Sciences, Federal University of Alagoas, Rio Largo, Alagoas, Brazil \\ ${ }^{2}$ Agricultural Engineering Academic Unit, Federal University of Campina Grande, Campina Grande, Paraíba, \\ Brazil \\ ${ }^{3}$ Science Center and Agri-Food Technologies, Federal University of Campina Grande, Pombal, Paraíba, Brazil \\ ${ }^{4}$ Center of Agrarian and Environmental Sciences, State University of Paraíba, Lagoa Seca, Paraíba, Brazil \\ Correspondence: Rener Luciano de Souza Ferraz, State University of Paraíba, Lagoa Seca, Paraíba, Brazil. Tel: \\ 55-083-3366-1297. E-mail: ferragroestat@gmail.com
}

Received: November 23, 2018

Accepted: January 19, 2019

Online Published: March 15, 2019

doi:10.5539/jas.v11n4p476

URL: https://doi.org/10.5539/jas.v11n4p476

\begin{abstract}
Wastewater use has become an alternative for agriculture in arid and semi-arid areas due to water scarcity besides providing nutrient for plants. This work aimed to evaluate the effects of the interaction of nitrogen and phosphorus doses associated with wastewater on the growth rate of eggplants in the stages of vegetative growth and beginning of fruiting in the semi-arid of Brazil. The wastewater was previously treated using sand filter with intermittent flow. The experiment consisted of a randomized block design in a $4 \times 4+1$ factorial scheme, with four replications. The factors consisted of four nitrogen doses $\left(\mathrm{N}_{1}=0.22, \mathrm{~N}_{2}=0.39, \mathrm{~N}_{3}=0.56\right.$ and $\mathrm{N}_{4}=0.72 \mathrm{~g}$ $\mathrm{dm}^{-3}$ of soil), four doses of phosphorus $\left(\mathrm{P}_{1}=0, \mathrm{P}_{2}=1.68, \mathrm{P}_{3}=2.40\right.$ and $\mathrm{P}_{4}=3.12 \mathrm{~g} \mathrm{dm}^{-3}$ of soil), both using wastewater, and a control treatment (100\% nitrogen and phosphorus using drinking water). The interaction of wastewater with nitrogen and phosphorus doses influenced all growth rates at the vegetative stage, except for the relative number of leaves. We found interaction for the relative rates of stem diameter and number and area of leaves at the beginning of the fruiting stage. Nitrogen and phosphorus doses associated with wastewater were excessive even below the recommendation for eggplant cultivation, however, in the absence of wastewater the plants reduce the growth rates of stem diameter and leaf area in the initial period of the fruiting.
\end{abstract}

Keywords: fertilization, Solanum melongena L., water reuse

\section{Introduction}

Eggplant (Solanum melongena L.) is a vegetable of the family Solanaceae originating from tropical regions of the East, has herbal properties, and relevant nutritional and medicinal characteristics (Oliveira et al., 2014). Eggplant adapts easily to climatic conditions and can be cultivated all year round in tropical and subtropical regions (Filgueira, 2008). However, the expansion of eggplant crops is limited by several factors, such as water and nutritional demand, commonly used indiscriminately leading to resource waste.

The irrigation of eggplant generally uses potable water, however, due to population increase and the seasonal droughts, the use of pure water has been limited. Eggplant produces satisfactorily $6.41 \mathrm{~kg}$ of fruits per plant, using $690.04 \mathrm{~mm}$ during the cycle (Lima et al., 2012), what is a relatively high water volume regarding the crop cycle. A way to mitigate this problem is the use of wastewater for irrigation of plants, as reported in several studies involving different crops, such as eggplant (Medeiros et al., 2017), tomato (Gatta et al., 2015), okra (Khaleel et al., 2013; Medeiros et al., 2018a, b) and sweet pepper (Iqbal et al., 2015).

The reuse of treated wastewater in irrigation is a practical solution to deal with water scarcity, especially in arid and semi-arid regions (Al-Jaboobi et al., 2014; Medeiros et al., 2018a). However, other cultivation practices should be associated such as the care with nutrition (Khaleel, Ismail, \& Ibrahim, 2013; Gatta et al., 2015; Medeiros et al., 2018b) because several nutrients are present in the wastewater, such as nitrogen and phosphorus 
(Medeiros et al., 2018a). Therefore, it is important to take into account the adequate amount of nutrients required by crops irrigated with wastewater.

According to Oliveira et al. (2014), nitrogen doses from 5 g per plant of eggplant did not increase the efficiency of this input. However, there are no reports of phosphorous addition associated with wastewater in the literature. Different nitrogen doses are recommended for other cultures, for example, $135 \mathrm{~kg} \mathrm{ha}^{-1}$ for sunflower (Ali \& Noorka, 2013) and $200 \mathrm{~kg} \mathrm{ha}^{-1}$ for common bean (Ribeiro, Leite, Costa, Albuquerque, \& Mielezrski, 2018) and okra (Medeiros et al., 2018a, 2018b). It is needed, however, to quantify the ideal phosphorus doses because its deficiency affects the physiological metabolism of plants, such as gas exchange and, consequently, growth and production (Hernández \& Munné-Bosch, 2015; Veronica et al., 2017). Also, an excess of phosphorus impairs the development of plants, damaging mainly the growth and biomass production (Melo et al., 2018).

Therefore, because wastewater is nutrient rich, and the adequate nutrient supply is essential for the growth and development of plants, this work aimed to evaluate the effects of the interaction of nitrogen and phosphorus doses associated with wastewater on the growth rate of eggplant plants during the stages of vegetative growth and beginning of fruiting in the semiarid of Brazil.

\section{Material and Methods}

\subsection{Localization, Experimental Design, Treatments and Plant Material}

The experiment was conducted in greenhouse at the Centro de Ciências e Tecnologia Agroalimentar (CCTA) of the Federal University of Campina Grande-UFCG, Pombal, Paraíba, Brazil. The site is situated at 6 $6^{\circ} 48^{\prime} 16^{\prime \prime} \mathrm{S}$, $37^{\circ} 49^{\prime} 15^{\prime \prime} \mathrm{W}$, with an average altitude of $144 \mathrm{~m}$.

The experimental design was completely randomized, with treatments arranged in a $4 \times 4+1$ factorial scheme, with four replications each, totalizing 68 experimental units. The factors consisted of four nitrogen doses $\left(\mathrm{N}_{1}=\right.$ $0.22, \mathrm{~N}_{2}=0.39, \mathrm{~N}_{3}=0.56$ and $\mathrm{N}_{4}=0.72 \mathrm{~g} \mathrm{dm}^{-3}$ of soil $)$ and four doses of phosphorus $\left(\mathrm{P}_{1}=0.96, \mathrm{P}_{2}=1.68, \mathrm{P}_{3}=\right.$ 2.40 and, $\mathrm{P}_{4}=3.12 \mathrm{~g} \mathrm{dm}^{-3}$ of soil), corresponding respectively to $40,70,100$ and $130 \%$ of recommended for fertilization of eggplant cultivation when cultivated in pots, suggested by Malavolta (2006), associated with the use of wastewater in the irrigation of the plants. In addition to these treatments, the control treatment consisted of $100 \%$ of the recommended dose of nitrogen and phosphorus irrigated with potable water. The control was compared with the treatments that received the minimum (40\%) and recommended (100\%) doses of nitrogen and phosphorus fertilization irrigated with wastewater.

We grow eggplant Embú in $20 \mathrm{~L}$ plastic pots, filled with $20 \mathrm{~kg}$ of soil. The soil was classified as sandy loam, non-saline and non-sodic, with the chemical and physical characteristics determined using the methodology recommended by Embrapa (1997) (Table 1).

Table 1. Chemical and physical attributes of the soil used during the experiment

\begin{tabular}{|c|c|c|c|c|c|c|c|c|c|c|c|c|}
\hline \multicolumn{13}{|c|}{ Chemical } \\
\hline $\mathrm{pH}_{\mathrm{es}}$ & $\mathrm{K}^{+}$ & $\mathrm{Na}^{+}$ & $\mathrm{Ca}^{2+}$ & $\mathrm{Mg}^{2+}$ & $\mathrm{H}+\mathrm{Al}$ & CEC & $\mathrm{EC}_{\mathrm{se}}$ & $\mathrm{N}$ & $\mathrm{OC}$ & $\mathrm{OM}$ & BS & $\mathrm{P}_{\text {Ass }}$ \\
\hline & $-\cdots$ & 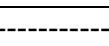 & $\overline{\mathrm{ol}_{\mathrm{c}} \mathrm{kg}}$ & ------ & --------- & \multicolumn{2}{|c|}{----- $\mathrm{dm}^{-1}$---- } & $-\cdots$ & $\mathrm{g} \mathrm{kg}$ & ------ & \multirow{2}{*}{$\begin{array}{l}\mathrm{cmol}_{\mathrm{c}} \mathrm{kg}^{-1} \\
8.6\end{array}$} & $\mathrm{mg} 100 \mathrm{~g}^{-1}$ \\
\hline 7.7 & 0.3 & 0.7 & 5.2 & 2.3 & 0.0 & 8.6 & 2.2 & 0.5 & 5.4 & 9.3 & & 4.6 \\
\hline \multicolumn{13}{|c|}{ Physical } \\
\hline \multicolumn{2}{|l|}{ Sand } & \multirow{2}{*}{$\begin{array}{l}\text { Silt } \\
-\mathrm{g} \mathrm{kg}^{-1}\end{array}$} & \multicolumn{2}{|l|}{ Clay } & \multicolumn{2}{|l|}{ Porosity } & DP & \multicolumn{3}{|c|}{$\mathrm{BD}$} & \multicolumn{2}{|c|}{ Water available } \\
\hline \multirow{2}{*}{\multicolumn{2}{|c|}{$\begin{array}{l}----\cdot \\
729\end{array}$}} & & - & ----- & \multicolumn{2}{|l|}{$\%$} & \multicolumn{4}{|c|}{ - } & \multicolumn{2}{|l|}{$\mathrm{g} \mathrm{kg}^{-1}$} \\
\hline & & 145 & 126 & & 50 & & 2.8 & & & & 73.9 & \\
\hline
\end{tabular}

Note. $\mathrm{pH}_{\mathrm{se}}=\mathrm{pH}$ of saturation extract, $\mathrm{K}^{+}=$Potassium, $\mathrm{Na}^{+}=$Sodium, $\mathrm{Ca}^{2+}=$ Calcium, $\mathrm{Mg}^{2+}=\mathrm{Magnesium}$, $\mathrm{H}+\mathrm{Al}=$ Hydrogen+Aluminium, $\mathrm{CEC}=$ Cation Exchange Capacity, $\mathrm{EC}_{\mathrm{es}}=$ Eletric Conductivity in the saturation extract, $\mathrm{N}=$ Nitrogen, $\mathrm{OC}=$ Organic Carbon, $\mathrm{OM}=$ Organic matter.

We produced the eggplant seedlings in expanded polystyrene trays of 128 cells, using a commercial substrate based on pine bark, hummus, and vermiculite. After twenty-five days of sowing (DAS), two seedlings were transplanted per pot, and at 17 days after transplanting (DAT), we performed the thinning leaving the more vigorous seedlings. During the experiment, the soil was maintained near the field capacity approach described by Medeiros et al. (2017) using wastewater and water supply, according to the treatments.

We used urea as nitrogen source $(45 \% \mathrm{~N})$. To avoid possible losses due to volatilization and/or leaching, nitrogen fertilization was divided in seven applications, every 7 DAT. 
The source of phosphorus was superphosphate $\left(18 \%\right.$ of $\left.\mathrm{P}_{2} \mathrm{O}_{5}\right)$, added as a basal fertilization five days before transplanting. Potassium fertilization was also carried out with potassium chloride in the amount of $0.31 \mathrm{~g} \mathrm{dm}^{-3}$, fertilized in the same period of nitrogen fertilizations.

The wastewater used in the experiment came from showers, sinks and urinals of the bathrooms of the UFCG, Campus de Pombal, collected by pipes and deposited in a septic tank. The tank was connected by a tube inserted at the lower end to a plastic container with $500 \mathrm{~L}$ capacity, functioning as effluent distribution tank. The distribution occurred using piping up three different intermittent aerobic filters (each filter receiving $50 \mathrm{~L}$ of wastewater every 6,8 and 12 hours). The effluent produced was stored in a plastic container with a capacity of $500 \mathrm{~L}$.

The filters were constructed adapting plastic containers with a capacity of $250 \mathrm{~L}$ each in the lower part of the container. The containers have three layers: a bottom layer of $10 \mathrm{~cm}$ of gravel $\left(\mathrm{n}^{\mathrm{o}} .1\right)$, a layer in the middle composed by $50 \mathrm{~cm}$ of sand and in the upper part another layer of $5 \mathrm{~cm}$ of gravel, to standardize the flow.

The physical-chemical characterization of the wastewater (mean values) before and after the treatment with sand filter (Sousa, 2015) is shown in Table 2. The results wastewater quality after the use of sand filter are within the standards recommended by Brazil (2005).

Table 2. Physical-chemical characteristics of the wastewater (RW) of the septic tank and after the sand filters

\begin{tabular}{|c|c|c|c|c|c|c|c|c|c|c|c|c|}
\hline \multicolumn{13}{|c|}{ Wastewater before filter } \\
\hline $\mathrm{pH}$ & $\mathrm{EC}_{\mathrm{a}}$ & DO & $\mathrm{Ca}$ & $\mathrm{Mg}$ & $\mathrm{Cl}^{-}$ & $\mathrm{P}$ & $\mathrm{N}$ & $\mathrm{Na}$ & $\mathrm{K}$ & COD & BOD & SAR \\
\hline & $\mathrm{dS} \mathrm{m}^{-1}$ & $-\cdots$ & ---- & $---\cdot-$ & - & ---- & $\mathrm{g} \mathrm{L}^{-1}-$ & 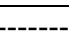 & --- & $-\cdots$ & ------- & $\mathrm{mmol} \mathrm{L}^{-1}$ \\
\hline 8.3 & 0.82 & 0.4 & 34.4 & 25.4 & 102.5 & 0.8 & 0.01 & 0.02 & 0.09 & 89.8 & 15.6 & 3.6 \\
\hline \multicolumn{13}{|c|}{ Wastewater after the sand filters } \\
\hline $\mathrm{pH}$ & $\mathrm{EC}_{\mathrm{a}}$ & DO & $\mathrm{Ca}$ & $\mathrm{Mg}$ & $\mathrm{Cl}^{-}$ & $\mathrm{P}$ & $\mathrm{N}$ & $\mathrm{Na}$ & $\mathrm{K}$ & COD & BOD & SAR \\
\hline & $\mathrm{dS} \mathrm{m}^{-1}$ & --- & --- & ---- & - & - & $g^{-1}-$ & $-\cdots$ & -- & --o--- & ------ & $\mathrm{mmol} \mathrm{L}^{-1}$ \\
\hline 6.2 & 0.56 & 6.4 & 58.4 & 44.0 & 86.2 & 0.7 & 0.01 & 0.01 & 0.0 & 127.3 & 25.4 & 1.3 \\
\hline
\end{tabular}

Note. $\mathrm{pH}=$ Hydrogenionic potential, $\mathrm{EC}=$ Eletric Conductivity, $\mathrm{DO}=$ Dissolved Oxygen, $\mathrm{Ca}=$ Calcium, $\mathrm{Mg}=$ Magnesium, $\mathrm{Cl}^{-}=$Cloretum, $\mathrm{P}=$ Fosforum, $\mathrm{N}=$ Nitrogen, $\mathrm{Na}=$ Sodium, $\mathrm{K}=$ Potassium, $\mathrm{DQO}=$ Chemical Oxygen Demand, $\mathrm{DBO}=$ Biochemical Oxygen Demand, $\mathrm{SAR}=$ Sodium Adsorption Ratio.

\subsection{Data Sampling}

We evaluate the height of plants (HP) [cm], number of leaves (LN), stem diameter (SD) [mm] and leaf area (LA) $\left[\mathrm{cm}^{2}\right]$ at 10,30 and 50 DAT. The height was measured by the distance between the collar of the plant and the base of the youngest leaf. During the counting of leaves we just considering leaves with complete development. The diameter was measured at $3 \mathrm{~cm}$ from the collar of the plant. Leaf areas were obtained according to the methodology proposed by Maldaner et al. (2009).

We calculated the absolute (AGR) and relative growth rate (RGR) using plant height and stem diameter, and the relative growth rate of leaf number and leaf area, both for the vegetative stage and for the beginning of the fruiting, using the evaluations obtained between 10 and 30 days after emergency (DAE), and between 30 and 50 DAE, respectively.

Absolute and relative growth rate of height and diameter were obtained through the methodology presented by Benincasa (2003):

$$
\mathrm{AGR}=\frac{\mathrm{M} 2-\mathrm{M} 1}{\mathrm{~T} 2-\mathrm{T} 1}
$$

AGR is the absolute growth rate, M1 is the measurement of the variable at time one (T1) and M2 the measure at the time 2 (T2).

$$
\mathrm{RGR}=\frac{\ln \mathrm{M} 2-\ln \mathrm{M} 1}{\mathrm{~T} 2-\mathrm{T} 1}
$$

RGR corresponds to the relative growth rate, $\ln$ is the neperian logarithm of the measured variable, M1 is the measurement of the variable at time one (T1) and M2 the measure at the time 2 (T2).

The relative rates of growth of leaf number and leaf area were obtained according to the methodology proposed by Wang et al. (2006): 


$$
\mathrm{RGR}=\frac{\mathrm{M} 2-\mathrm{M} 1}{\mathrm{M} 1} \times 100
$$

RGR corresponds to the relative growth rate, and M1 and M2 correspond to the beginning and end variable evaluations, respectively, of each stage.

\subsection{Data Analysis}

We used an analysis of variance by the F test $(p<0.05)$ to understand the effects of phosphorous and nitrogen doses and its interaction on the growth of eggplant. I the case of significance, a polynomial regression analysis was performed to split the phosphorus doses into nitrogen. A Tukey test was performed to compare the means of the treatment that was irrigated with drinking water and received $100 \%$ of nitrogen and phosphorus dose according to the recommendation (Control treatment) with those irrigated with wastewater with $40 \%$ and $100 \%$ of nitrogen and phosphorus. The analyses were performed at the statistical software SISVAR (Ferreira, 2014).

\section{Results}

We found a significant interaction among nitrogen and phosphorous doses for absolute growth in plant height and stem diameter at the vegetative stage. Only the diameter of the stem showed no interaction effect at the initial fruiting stage (Table 3). We also found interaction of $\mathrm{N} x \mathrm{P}$, for the relative growth rate of leaf number at the beginning of fruiting, and leaf area for the two evaluated periods.

According to Tukey's test, we observed different absolute growth rate in height of plants between the two types of water used (wastewater and potable water) at the vegetative stage, and different relative growth rate of Leaf area, and absolute and relative growth rate of stem diameter at initial stage of fruiting (Table 3).

Table 3. Summary of the Analysis of Variance for the absolute growth rate (AGR) and relative growth rate (RGR) of plant height (RGR-PH), stem diameter (RGR-SD), number of leaves (RGR-LN) and leaf area (RGR-LA) in the vegetative and initial fruiting stages of the eggplant under irrigation with wastewater, nitrogen and phosphate fertilization

\begin{tabular}{|c|c|c|c|c|c|c|}
\hline \multirow{2}{*}{ Source of Variation } & \multicolumn{6}{|c|}{ Test $F$} \\
\hline & AGR-PH & AGR-SD & RGR-PH & RGR-SD & RGR-LN & RGR-LA \\
\hline \multicolumn{7}{|l|}{ Stage vegetative } \\
\hline Nitrogen $(\mathrm{N})$ & $7.73 * *$ & $5.81^{* *}$ & $6.85 * *$ & $3.28 *$ & $1.20^{\mathrm{ns}}$ & $5.25 * *$ \\
\hline Phosphorus (P) & $2.43^{\mathrm{ns}}$ & $7.03^{* *}$ & $1.51^{\mathrm{ns}}$ & $3.23 *$ & $1.90^{\mathrm{ns}}$ & $3.00 * *$ \\
\hline Interaction $(\mathrm{N} \times \mathrm{P})$ & $4.40 * *$ & $5.80 * *$ & $3.20 * *$ & $6.36^{* *}$ & $1.03^{\mathrm{ns}}$ & $2.32 *$ \\
\hline Block & 1.93 & 0.52 & 3.70 & 0.58 & 0.82 & 0.40 \\
\hline Treatments & \multicolumn{6}{|l|}{ Averages } \\
\hline $\mathrm{N}_{1} \mathrm{P}_{1}$ & $0.437 \mathrm{~b}$ & $0.226 a$ & $0.047 \mathrm{a}$ & $0.047 \mathrm{a}$ & $97.85 \mathrm{a}$ & $988.83 \mathrm{a}$ \\
\hline $\mathrm{N}_{3} \mathrm{P}_{3}$ & $0.618 \mathrm{ab}$ & $0.212 \mathrm{a}$ & $0.056 \mathrm{a}$ & $0.043 \mathrm{a}$ & $82.14 \mathrm{a}$ & $870.86 \mathrm{a}$ \\
\hline Control & $0.739 a$ & $0.249 \mathrm{a}$ & $0.060 \mathrm{a}$ & $0.043 \mathrm{a}$ & $112.50 \mathrm{a}$ & $958.63 \mathrm{a}$ \\
\hline \multicolumn{7}{|l|}{ Initial fruiting } \\
\hline Nitrogen $(\mathrm{N})$ & $1.02^{\mathrm{ns}}$ & $0.63^{\mathrm{ns}}$ & $3.59 *$ & $1.06^{\mathrm{ns}}$ & $0.73^{\mathrm{ns}}$ & $33.33 * *$ \\
\hline Phosphorus (P) & $0.56^{\mathrm{ns}}$ & $0.92^{\mathrm{ns}}$ & $1.13^{\mathrm{ns}}$ & $1.83^{\mathrm{ns}}$ & $3.93^{*}$ & $5.14 * *$ \\
\hline Interaction $(\mathrm{N} \times \mathrm{P})$ & $1.07^{\mathrm{ns}}$ & $0.62^{\mathrm{ns}}$ & $2.23 *$ & $1.02^{\mathrm{ns}}$ & $2.18^{*}$ & $7.81^{* *}$ \\
\hline Block & 1.24 & 0.48 & 1.07 & 0.33 & 1.59 & 0.64 \\
\hline Treatments & \multicolumn{6}{|l|}{ Averages } \\
\hline $\mathrm{N}_{1} \mathrm{P}_{1}$ & $1.681 \mathrm{a}$ & $0.259 \mathrm{a}$ & $0.060 \mathrm{a}$ & $0.026 \mathrm{a}$ & $189.01 \mathrm{a}$ & $263.74 \mathrm{~b}$ \\
\hline $\mathrm{N}_{3} \mathrm{P}_{3}$ & $1.825 \mathrm{a}$ & $0.243 a$ & $0.055 \mathrm{a}$ & $0.025 \mathrm{a}$ & $216.47 \mathrm{a}$ & $369.96 \mathrm{a}$ \\
\hline Control & $1.754 \mathrm{a}$ & $0.158 b$ & $0.048 \mathrm{a}$ & $0.015 b$ & $233.82 \mathrm{a}$ & $233.62 b$ \\
\hline
\end{tabular}

Note. $^{\text {ns }}=$ not significant, $* *, *=$ significant at 1 and $5 \%$ probability by F-test, respectively, Means followed by the same letter in the column do not differ by Tukey's test at $5 \%$ probability level $(p<0.05) . \mathrm{N}_{1} \mathrm{P}_{1}:\left(0.22 \mathrm{~g} \mathrm{dm}^{-3}\right.$ of nitrogen $+0.96 \mathrm{~g} \mathrm{dm}^{-3}$ of phosphorous + wastewater $)=$ treatments with wastewater and $40 \%$ of nitrogen and phosphorous recommendation, $\mathrm{N}_{3} \mathrm{P}_{3}:\left(0.56 \mathrm{~g} \mathrm{dm}^{-3}\right.$ of nitrogen $+2.40 \mathrm{~g} \mathrm{dm}^{-3}$ of phosphorous + wastewater $)=$ treatments with wastewater and $100 \%$ of nitrogen and phosphorous recommendation, Control: $\left(0.56 \mathrm{~g} \mathrm{dm}^{-3}\right.$ of nitrogen $+2.40 \mathrm{~g} \mathrm{dm}^{-3}$ of phosphorous + potable water $)=$ plants that received irrigation with potable water and $100 \%$ of the recommended dose of nitrogen and phosphorous. 
The absolute growth rate of plant height at the vegetative stage increased to $0.93 \mathrm{~cm} \mathrm{~d}^{-1}$ using the lowest applied phosphorus dose $\left(0.96 \mathrm{~g} \mathrm{dm}^{-3}\right)$ and $0.46 \mathrm{~g} \mathrm{dm}^{-3}$ of nitrogen (Figure 1a). However, phosphorus doses of 1.68 and $2.40 \mathrm{~g} \mathrm{dm}^{-3}$ reduced ARG-PH in 11.7 and $26.6 \%$, respectively, with the increase in nitrogen doses. The highest dose of phosphorus $\left(3.12 \mathrm{~g} \mathrm{dm}^{-3}\right)$ did not influence the variables evaluated. At the same growth stage, AGR-SD decreased with the increase in the nitrogen doses at $0.9,1.68$ and $2.40 \mathrm{~g} \mathrm{dm}^{-3}$ of phosphorus, these reductions were 23.2, 21.2 and 18.2\%, respectively (Figure 1b). The highest dose of phosphorus ( $\left.3.12 \mathrm{~g} \mathrm{dm}^{-3}\right)$ did not affect the growth rates.

The growth rate of plant height was similar between treatments $\mathrm{N}_{3} \mathrm{P}_{3}$ and control (wastewater $\mathrm{x}$ potable water) and were larger than in $\mathrm{N}_{1} \mathrm{P}_{1}$ treatment (Table 3).
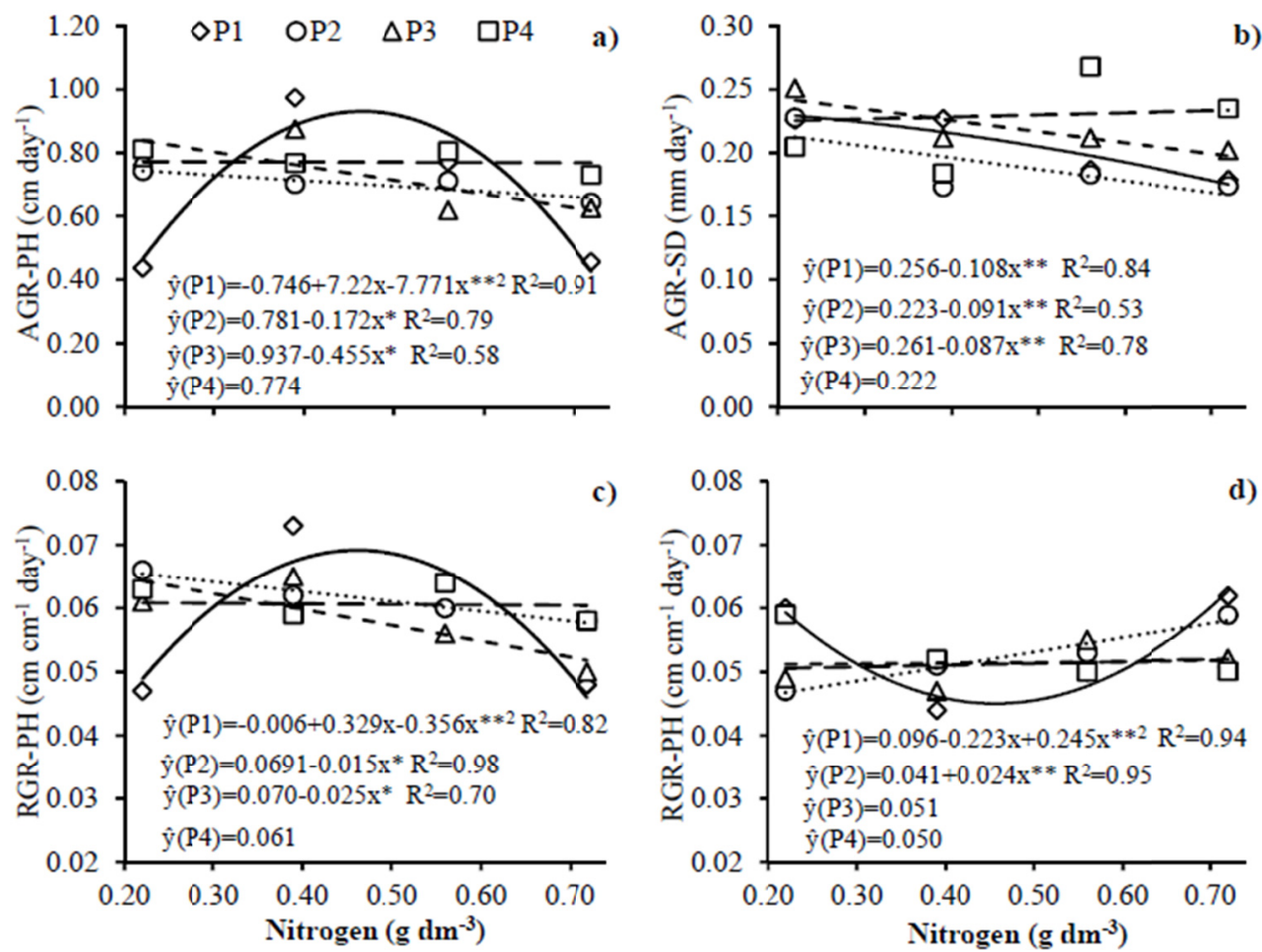

Figure 1. Absolute growth rate of plant height-AGR-PH (a) and absolute growth rate of stem diameter-AGR-SD (b) in the vegetative stage; relative growth rate of plant heigh-RGR-PH in the vegetative stage (c) and initial fruiting (d) as a function of nitrogen and phosphorus doses in eggplant irrigated with wastewater

Similar to AGR, RGR-PH increased up to $0.070 \mathrm{~cm}^{-1}$ day ${ }^{-1}$ using the lowest phosphorus dose $\left(0.96 \mathrm{dm}^{-3}\right)$ until the estimated dose of $0.46 \mathrm{~g} \mathrm{dm}^{-3}$ of nitrogen at the vegetative stage (Figure 1c). The doses of phosphorus 1.68 and $2.40 \mathrm{~g} \mathrm{dm}^{-3}$ lead to a decrease of $10.8 \%$ and $20 \%$ in RGR-PH with the increase of nitrogen, respectively.

At the initial fruiting stage the RGR-PH increased up to $0.045 \mathrm{~cm}^{-1}$ day ${ }^{-1}$ with the lowest phosphorus dose $(0.96$ $\mathrm{dm}^{-3}$ ) until the estimated dose of $0.45 \mathrm{~g} \mathrm{dm}^{-3}$ nitrogen, whereas the dose of $1.68 \mathrm{~g} \mathrm{dm}^{-3}$ of phosphorus associated with the increase of nitrogen reduced by $26 \%$ with nitrogen increase, while the two highest doses of phosphorus ( 2.40 and $3.12 \mathrm{~g} \mathrm{dm}^{-3}$ ) did not influence on the relative growth of plant height at the initial fruiting stage, with the increase in nitrogen doses (Figure 1d).

The relative growth rate of stem diameter (RGR-SD) at the initial fruiting stage reduced at the phosphorus doses $0.96,1.68$ and $2.40 \mathrm{~g} \mathrm{dm}^{-3}$ with the increase in nitrogen doses $(22.9,20.4$ and $26.9 \%$ of decrease, respectively) (Figure 2a). The higher dose of phosphorus did not influence RGR-SD (Figure 2a).

Comparing treatments with different types of waters, AGR and RGR-PH were similar between treatments $\mathrm{N}_{1} \mathrm{P}_{1}$ and $\mathrm{N}_{3} \mathrm{P}_{3}$ but were higher than the control at the beginning of fruiting (Table 3 ). 

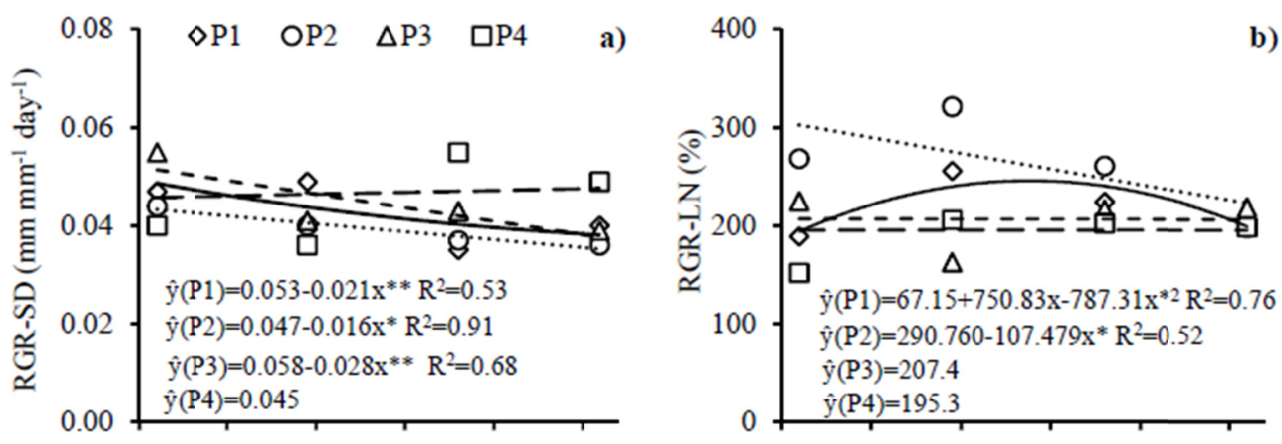

b)
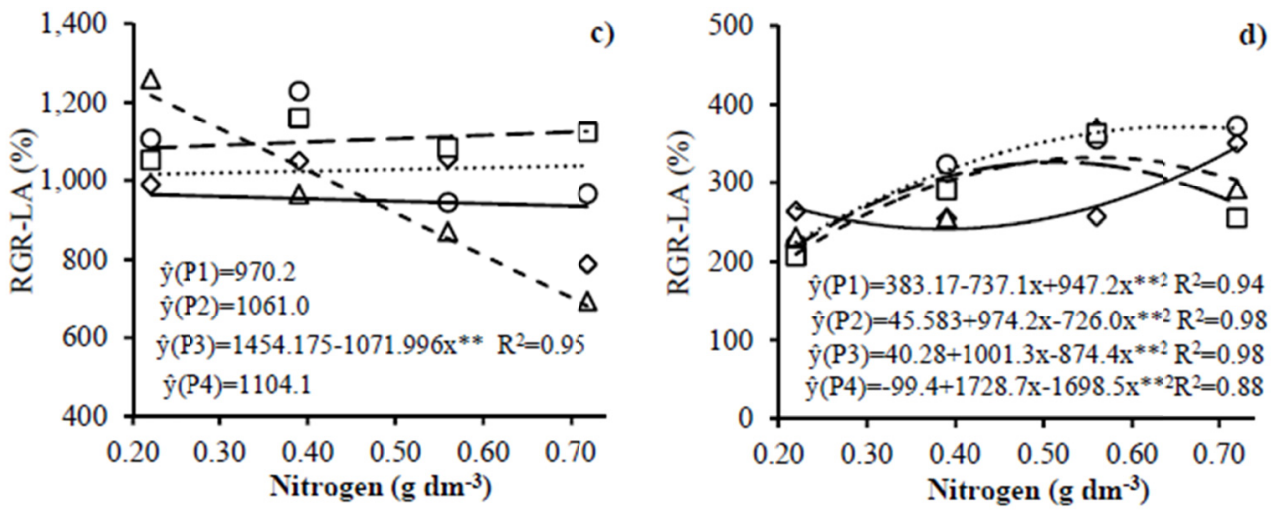

Figure 2. Relative growth rate of stem diameter-AGR-SD (a) at the vegetative stage; relative growth rate of number leaves - RGR-LN during the initial frutification (b); and relative growth rate of leaf area-RGR-LA at the vegetative stage (c) and initial frutification (d) as a function of nitrogen and phosphorus doses in eggplant irrigated with wastewater

RGR-LN only varied between nitrogen and phosphorus doses at the initial fruiting stage. We found an increase in RGR-LN of $246.1 \%$ up to the estimated nitrogen dose of $0.47 \mathrm{~g} \mathrm{dm}^{-3}$ at the treatment with the lowest phosphorus dose $\left(0.96 \mathrm{dm}^{-3}\right)$ (Figure $2 \mathrm{~b}$ ), and a decrease of $20.1 \%$ at the phosphorous dose of $1.68 \mathrm{~g} \mathrm{dm}^{-3}$ with the increase in nitrogen. Phosphorus doses of 2.40 and $3.12 \mathrm{~g} \mathrm{dm}^{-3}$ did not influence the growth rates in number of leaves of eggplant.

RGR-LA varied between nitrogen and phosphorus doses both at the vegetative and at the beginning of fruiting. At the vegetative stage, the RGR-LA was affected only by the dose of phosphorus $2.40 \mathrm{~g} \mathrm{dm}^{-3}$, showing a decrease of $44 \%$ with increasing doses of nitrogen fertilizer (Figure 2c). At the initial fruiting stage, RGR-LA was lower $(241.7 \%)$ at the phosphorus dose $0.96 \mathrm{~g} \mathrm{dm}^{-3}$ and the estimated nitrogen dose $0.38 \mathrm{dm}^{-3}$. At phosphorus doses $1.68,2.40$ and $3.12 \mathrm{~g} \mathrm{dm}^{-3}$ the RGR-LA increased $372.4 ; 327$ and 340.3\%, respectively, with the estimated doses of nitrogen $0.67,0.57$ and $0.50 \mathrm{~g} \mathrm{dm}^{-3}$ (Figure $2 \mathrm{~d}$ ).

Comparing the treatments with different types of water used in the irrigation, AGR-PH was similar between $\mathrm{N}_{1} \mathrm{P}_{1}$ and the control but had smaller values of growth than the $\mathrm{N}_{3} \mathrm{P}_{3}$ treatment (Table 3 ).

\section{Discussion}

The use of wastewater in agriculture is a promising technique providing, in addition to water supply, the increase in soil organic matter and release of mineral nutrients that may favor plant (Al-Jaboobi et al., 2014; Gatta et al., 2015; Iqbal et al., 2015; Medeiros et al., 2018a). Several studies report that the concentration of essential nutrients, such as N, P, K, Ca and Mg, was higher in wastewater than in drinking water (Al-Jaboobi et al., 2015; Gatta et al., 2015; Iqbal et al., 2015), a result that probably occurred in this study, where nutrients played beneficial roles in eggplants when irrigated with wastewater (Al-Jaboobi et al., 2014; Gatta et al., 2015; Medeiros et al. 2017) as observed in the relative growth rate of stem diameter and leaf area at the initial fruiting stage (50 DAT). A similar result was found for okra crop, where the use of wastewater with nitrogen fertilization increased the leaf area (Medeiros et al., 2018a). Iqbal et al. (2015) observed a higher height and number of leaves using wastewater concerning to drinking water. Residual water also contributes to plant growth by adding organic matter to the soil, improving physical-chemical characteristics and favoring microbiological activity (Al-Jaboobi et al., 2014). 
The reductions in the absolute and relative growth rate of plant height and stem diameter during the vegetative stage with the increase of nitrogen at lower doses of phosphorus probably occurred due to the supply of these nutrients by the wastewater. The results suggest a nutritional excess caused by the use of wastewater in addition to the high doses of nitrogen and phosphorus. Furtado and Chaves (2018) observed that the application of NPK from $60 \%$ of the recommended dose caused the reduction of the absolute growth rate of stem diameter. Oliveira et al. (2014), also observed that high doses of nitrogen promoted a reduction in the yield of eggplant crop by potentiating the harmful effects of water salinity and, therefore, decreased the agronomic efficiency of nitrogen fertilization. In this study, the increase of nitrogen doses with the use of wastewater possibly increased the electrical conductivity of the culture medium and, consequently, decreased plant growth rates. The increase in soil electrical conductivity reduces the osmotic potential making it impossible to absorb water and nutrients, besides the ionic toxicity of certain ions negatively affect plant growth (Oliveira et al., 2014).

Among the nutrients in the wastewater, nitrogen and phosphorus require attention due to the high concentration in the effluents, besides they play important functions for the vegetables (Medeiros et al., 2017). Nitrogen is one of the most important nutrients performing structural function by being part of several organic compounds (Oliveira et al., 2014). However, nitrogen excess acidifies the soil. Due to the high doses of nitrogen fertilizer and the use of wastewater it is possible that acidification may have occurred in our experiment and promoted a nutritional imbalance and toxic effect on the plants (Medeiros et al., 2017, 2018b). Also, phosphorus excess results in low efficiency of its use, cause serious environmental consequences and may accelerate the depletion of its mineral reserves (Hasan, Hasan, Teixeira da Silva, \& Li, 2016). The excess of both nutrients is a negative factor for the nutritional management of crops, and their use must adequately meet the nutritional requirements of the plants.

Proper mineral nutrition is essential for plant growth, as observed by the nitrogen supply in the growth of bean plants (Ribeiro et al., 2018), okra (Medeiros et al., 2018a) and eggplant (Medeiros et al., 2017; Souza et al., 2017). Phosphorus levels also promoted adequate growth in rice plants (Veronica et al., 2017), strawberry (Medeiros et al., 2015) and wheat (Rodríguez, Keltjens, \& Goudriaan, 1998). Besides increase the plant growth and production, providing adequate amounts of nutrients allows the sustainable use of fertilizers (Silva et al., 2015). We verified in this study that the relative growth of plant height was influenced by the fertilization of nitrogen and phosphorus associated to wastewater, only at the vegetative stage, while leaf growth was affected at the beginning of fruiting. The plant growth was probably due to nitrogen supply, involved in cell division and stretching (Iqbal et al., 2015), and phosphorus, promoting root respiration, increasing plant growth when adequately supplied (Melo et al., 2018).

Leaf growth (RGR-LN) was affected only at the lowest phosphorus doses with the nitrogen increase, during the initial fruiting stage. However, just the dose equivalent to $100 \%$ of the phosphorus recommendation associated to the nitrogen increase negatively affected RGR-LA during the vegetative stage, whereas at the beginning of fruiting the rise of phosphate doses together with nitrogen reduced RGR-LA. The expansion of the leaves is an essential characteristic of vegetal production due to the directly involvement in photosynthesis. Adequate doses of nitrogen allow rapid growth in the leaf area of eggplants, enhancing the leaf area from the beginning of the growth increasing production (Souza et al., 2017). Souza et al. (2017) observed that high doses of nitrogen reduced the yield of the crop, where doses greater than $14 \mathrm{~g}$ plant $^{-1}$ decreased the number of fruits, possibly by reductions in the plant growth. The decrease of RGR-LA at the beginning of fruiting due to increased fertilization may be related to the onset of leaf senescence and lower nutrient requirement, such as phosphorus (Melo et al., 2018) or its limitation inhibiting leaf expansion (Figure 1) as a consequence of photosynthetic restriction (Veronica et al., 2017).

The highest growth of eggplant plants in this study can be attributed to the increased availability and continuous supply of nutrients by wastewater. Thus, the higher growth rates observed up to a certain limit of the application of nitrogen and phosphorus reflect the nutrient absorption, indicating that the use of wastewater may reduce the application of synthetic fertilizers. Tak, Ahmad, Babalola, and Inam (2012) report that wastewaters have a large concentration of essential nutrients to maintain soil fertility, as well as to increase growth and plant productivity. The concentration of nutrients of wastewater is important for agriculture, and when used correctly, can meet the needs of water by plants and reduce the demand for fertilizers contributing to the preservation of the environment (Iqbal et al. 2015; Medeiros et al., 2018b).

Although the wastewater does not entirely satisfy the nutritional requirements of the plants, it provides nutrients gradually, and fertilization with doses below the required by the plants can be excessive when associated to wastewater and negatively affect plant growth. Therefore, further research involving wastewater and other mineral nutrients are important and still needed. 


\section{Conclusions}

The application of nitrogen and phosphorus doses associated with wastewater becomes excessive even using the recommended nutrient dose for eggplant cultivation. However, in the absence of wastewater, the plants reduced the growth rates of the stem diameter and leaf area during the initial period of fruiting.

\section{References}

Ali, A., \& Noorka, I. R. (2013). Nitrogen and phosphorus management strategy for better growth and yield of sunflower (Helianthus annuus L.) hybrid. Soil \& Environment, 32, 44-48.

Al-Jaboobi, M., Tijane, M., El-Ariqi, S., El Housni, A., Zouahri, A., \& Bouksaim, M. (2014). Assessment of the impact of wastewater use on soil properties. Journal of Materials and Environmental Science, 5(3) 747-752.

Benincasa, M. M. P. (2003). Análise de crescimento de plantas (p. 41). Jaboticabal, SP, FUNEP.

Brazil, Distrito Federal, Brasília. (2005). Resolução $n^{\circ} 357$ de 17 de março de 2005 (p. 23). Conselho Nacional do Meio Ambiente (CONAMA), Diário Oficial da República Federativa do Brasil. Retrieved from http://www.mma.gov.br/port/conama/legiabre.cfm?codlegi=459

EMBRAPA (Brazilian Agricultural Research Corporation). (1997). Manual de métodos de análise de solo (p. 212). Centro Nacional de Pesquisa de Solos, Rio de Janeiro, Brazil.

Ferreira, D. F. (2014). SISVAR: A guide for its bootstrap procedures in multiple comparisons. Ciência \& Agrotecnologia, 38(2), 109-112. https://doi.org/10.1590/S1413-70542014000200001

Filgueira, F. A. R. (2008). Novo manual de olericultura: Agrotecnologia moderna, produção e comercialização de hortaliças (2nd ed., p. 421). Viçosa: UFV.

Furtado, G. F., \& Chaves, L. H. G. (2018). Growth rates and sunflower production in function of fertilization with biochar and NPK. Journal of Agricultural Science, 10(2), 260-270. https://doi.org/10.5539/ jas.v10n2p260

Gatta, G., Libutti, A., Gagliardi, A., Beneduce, L., Brusetti, L., Borruso, L., ... Tarantino, E. (2015). Treated agro-industrial wastewater irrigation of tomato crop: Effects on qualitative/quantitative characteristics of production and microbiological properties of the soil. Agricultural Water Management, 149, 33-43. https://doi.org/10.1016/j.agwat.2014.10.016

Hasan, M. M., Hasan, M. M., Teixeira da Silva, J. A., \& Li, X. (2016). Regulation of phosphorus uptake and utilization: Transitioning from current knowledge to practical strategies. Cellular \& Molecular Biology Letters, 21(7), 1-19. https://doi.org/10.1186/s11658-016-0008-y

Hernández, I., \& Munné-Bosch, S. (2015). Linking phosphorus availability with photo-oxidative stress in plants. Journal of Experimental Botany, 66(10), 2889-2900. https://doi.10.1093/jxb/erv056

Iqbal, S., Tak, H. I., Inam, A., Inam, A., Sahay, S., \& Chalkoo, S. (2015). Comparative effect of wastewater and groundwater irrigation along with nitrogenous fertilizer on growth, photosynthesis and productivity of chilli (Capsicum annuum L.). Journal of Plant Nutrition, 38, 1006-1021. https://doi.10.1080/01904167.2014. 991032

Khaleel, R. I., Ismail, N., \& Ibrahim, M. H. (2013). The Impact of waste water treatments on seed germination and biochemical parameter of Abelmoschus esculentus L. Procedia-Social and Behavioral Sciences, 91, 453-460. https://doi.org/10.1016/j.sbspro.2013.08.443

Lima, M. E., Carvalho, D. F., Souza, A. P., Rocha, H. S., \& Guerra, J. G. M. (2012). Desempenho do cultivo da berinjela em plantio direto submetida a diferentes lâminas de irrigação. Revista Brasileira de Engenharia Agrícola e Ambiental, 16(6), 604-610. https://doi.org/10.1590/S1415-43662012000600003

Malavolta, E. (2006). Manual de nutrição mineral de plantas (p. 638). São Paulo: CERES.

Maldaner, I. C., Guse, F. I., Streck, N. A., Heldwein, A. B., Lucas, D. D. P., \& Loose, L. H. (2009). Filocrono, área foliar e produtividade de frutos de berinjela conduzidas com uma e duas hastes por planta em estufa plástica. Ciência Rural, 39(3), 671-677. https://doi.org/10.1590/S0103-84782009005000013

Medeiros R. F., Pereira, W. E., Rodrigues, R. M., Nascimento, R., Suassuna, J. F., \& Dantas, T. A. G. (2017). Growth and yield of strawberry plants fertilized with nitrogen and phosphorus. Revista Brasileira de Engenharia Agrícola e Ambiental, 19(9), 865-870. https://doi.org/10.1590/1807-1929/agriambi.v19n9p 865-870 
Medeiros, A. S., Nobre, R. G., Campos, A. C., Queiroz, M. M. F., Magalhães, I. D., \& Ferraz, R. L. S. (2017). Características biométricas e acúmulo de fitomassa da berinjeleira sob irrigação com água residuária e doses de nitrogênio e fósforo. Revista Brasileira de Agricultura Irrigada, 11(7), 1975-1985. https://doi.org/ 10.7127/rbai.v11n700665

Medeiros, A. S., Alves, F. I. S., Feraz, R. L. S., Campos, A. C., Queiroz, M. M. F., \& Magalhães, I. D. (2018b). Crescimento e alocação de fitomassa do quiabeiro submetido à doses de nitrogênio e irrigação com água residuária. Revista Brasileira de Agricultura Irrigada, 12(3), 2621-2631. https://doi.org/10.7127/rbai. $\mathrm{v} 12 \mathrm{n} 300775$

Medeiros, A. S., Queiroz, M. M. F., Araújo Neto, R. A., Costa, P. S., Campos, A. C., Feraz, R. L. S., ... Gonzaga, G. B. M. (2018a). Yield of the okra submitted to nitrogen rates and wastewater in Northeast Brazilian semiarid region. Journal of Agricultural Science, 10(4), 409-416. https://doi.org/10.5539/jas.v10n4p409

Melo, N. C., Fernandes, A. R., Galvão, J. R., Alves Silva, V. F., Silva, D. R., Viégas, I. M., ... Galate, R. S. (2018). Yield of Pennisetum glaucum L. under phosphate source doses. Journal of Agricultural Science, 10(6), 146-153. https://doi.org/10.5539/jas.v10n6p146

Oliveira, F. A., Medeiros, J. F., Alves, R. C., Linhares, P. S. F., Medeiros, A. M. A., \& Oliveira, M. K. T. (2014). Interação entre salinidade da água de irrigação e adubação nitrogenada na cultura da berinjela. Revista Brasileira de Engenharia Agrícola e Ambiental, 18, 480-486. https://doi.org/10.1590/S1415-4366201400 0500003

Ribeiro, J. E. S., Leite, A. P., Costa, J. E., Albuquerque, M. B., \& Mielezrski, F. (2018). Development, physiology and productivity of the common bean under different nitrogen doses. Journal of Agricultural Science, 10(6), 171-183. https://doi.org/10.5539/jas.v10n6p171

Rodríguez, D., Keltjens, W. G., \& Goudriaan, J. (1998). Plant leaf area expansion and assimilate production in wheat (Triticum aestivum L.) growing under low phosphorus conditions. Plant and Soil, 200, 227-240. https://doi.org/10.1023/A:1004310217694

Silva, F. P. M., Giacon, G. M., Soares, J. S., Rosa, Y. B. C. J., Rosa, D. B. C. J., Lemes, C. S. R., ... Gutierrez, R. S. (2015). Crescimento e desenvolvimento de Hemerocallis fulva submetidos a doses de nitrogênio e fósforo. Ornamental Horticulture, 21(3), 351-362. https://doi.org/10.14295/oh.v21i3.738

Sousa, E. P. (2015). Qualidade físico-química e microbiológica de água residuária doméstica pós-tratada em fluxo descendente intermitente $(90$ f., Dissertação (Mestrado Profissional em Sistemas Agroindustriais), Universidade Federal de Campina Grande, Pombal).

Souza, Á. H. C., Rezende, R., Lorenzoni, M. Z., Seron, C. C., Hachmann, T. L., \& Lozano, C. S. (2017). Response of eggplant crop fertigated with doses of nitrogen and potassium. Revista Brasileira de Engenharia Agrícola e Ambiental, 21(1), 21-26. https://doi.org/10.1590/1807-1929/agriambi.v21n1p21-26

Tak, H. I., Ahmad, F., Babalola, O. O., \& Inam, A. (2012). Growth, photosynthesis and yield of chickpea as influenced by urban wastewater and different levels of phosphorus. International Journal of Plant Research, 2(2), 6-13. https://doi.org/10.5923/j.plant.20120202.02

Veronica, N., Subrahmanyam, D., Vishnu Kiran, T., Yugandhar, P., Bhadana, V. P., Padma, V., ... Voleti, S. R. (2017). Influence of low phosphorus concentration on leaf photosynthetic characteristics and antioxidant response of rice genotypes. Photosynthetica, 55(2), 285-293. https://doi.org/10.1007/s11099-016-0640-4

Wang ,Y., Jiang, J., Zhao, X., Liu, G., Yang, C., \& Zhan, L. (2006). A novel LEA gene from Tamarix androssowii confers drought tolerance in transgenic tobacco. Plant Science, 171, 655-662. https://doi.org/10.1016/ j.plantsci.2006.06.011

\section{Copyrights}

Copyright for this article is retained by the author(s), with first publication rights granted to the journal.

This is an open-access article distributed under the terms and conditions of the Creative Commons Attribution license (http://creativecommons.org/licenses/by/4.0/). 